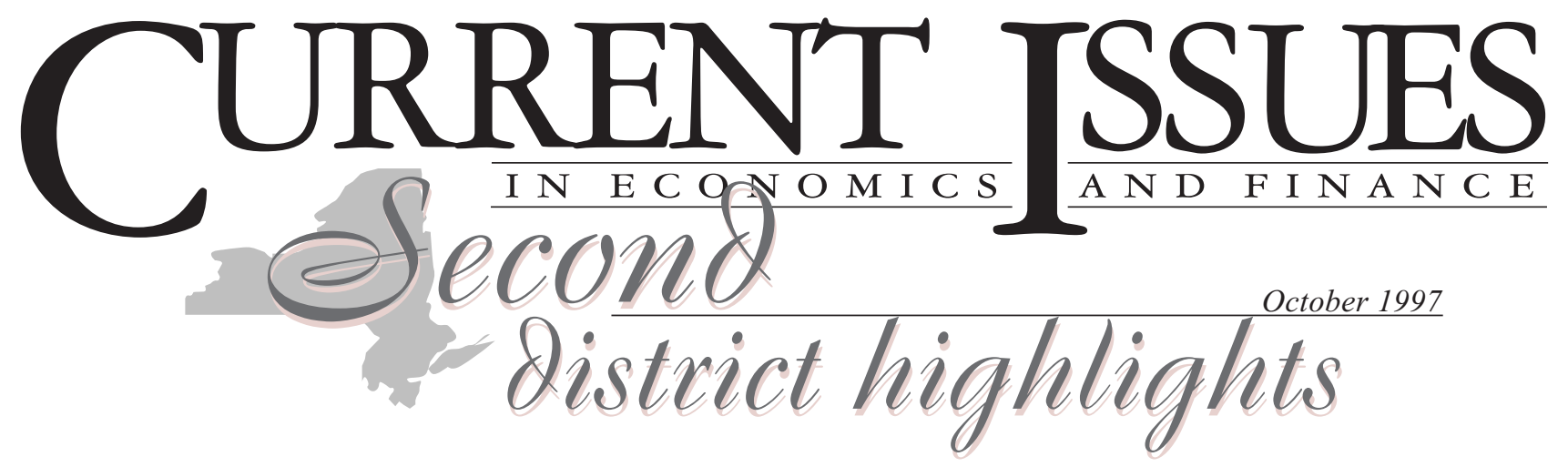

\title{
The New York-New Jersey Job Recovery
}

\section{James Orr and Rae D. Rosen}

Employment in the New York-New Jersey region has been rising steadily since the steep economic downturn of 1989-92, and the job recovery to date shows no signs of slowing. An improving national economy, the easing of large-scale downsizings in manufacturing, and an end to sweeping government cutbacks should help

\section{- Note from the Editor}

The Federal Reserve Bank of New York is pleased to present the first issue of Second District Highlights, a regional supplement to Current Issues in Economics and Finance. This new publication will report on financial and economic developments in the Second Federal Reserve District, which encompasses New York State, the twelve northern counties of New Jersey, and Connecticut's Fairfield County, as well as Puerto Rico and the Virgin Islands.

Employment growth, industry trends, income distribution, and business conditions are some of the topics we will cover in Second District Highlights. In addition, each issue will feature a series of charts tracking the region's major economic indicators.

As a Current Issues reader, you will receive Second District Highlights on a regular basis, so there's no need to subscribe. You can also obtain issues electronically from the Federal Reserve Bank of New York's publications web site (www.ny.frb.org/rmaghome). keep growth advancing throughout the year. According to current projections, employment in the New York-New Jersey region will rise about 1 percent in 1997, a rate of growth that slightly exceeds the 1996 pace. Largely responsible for this acceleration are the service and retail trade sectors, which together generated more than 500,000 jobs between 1993 and 1996. In the first half of this year, as in 1996, employment growth in several segments of services and retail trade approached or exceeded nationwide rates.

Not all industries have enjoyed the benefits of recovery, however. In many of the region's sectors, job creation has been consistently flat. Moreover, last year, the distribution of job growth took an uneven turn within New York State. In 1996, employment in the New York City metropolitan area-New York City, Long Island, and Putnam, Rockland, and Westchester Counties - expanded by nearly a full percentage point. Meanwhile, growth in upstate and western New York was close to zero. ${ }^{1}$ Without the surge in the New York metropolitan area, the rate of job growth in New York State would have been among the lowest in the nation. The strength of New York metropolitan area job gains and New Jersey's steady employment growth, however, have succeeded in keeping the recovery on track.

This first issue of Second District Highlights analyzes employment growth by sector in the New York-New Jersey region since 1993. It also profiles the geographic distribution of gains and identifies the sectoral developments underlying the growth patterns within New York State. In addition, we present an updated forecast of 1997 job growth for the entire region and for New York State, New York City, and New Jersey individually. 


\section{The Engines of Regional Job Growth}

The employment recovery in the New York-New Jersey region has been led by relatively robust growth in services and retail trade (Chart 1). The service sector accounts for a little less than a third ( 32 percent) of total regional employment but was responsible for the bulk of the region's new jobs. From the start of the recovery in 1993 to 1996, the region's service sector has added about 1 percentage point annually to total job growth. Jobs in this sector fall into three major

\section{Job levels in several segments of services and retail trade have surpassed prerecession peaks and have resumed their long-term growth trends.}

categories: business services, including accounting, marketing, consulting, legal, and computer services; consumer services, including educational, recreational, and cultural services; and health and social services. In the past four years, employment gains in the service sector (414,000 jobs) have exceeded the region's cumulative job growth $(379,500)$.

The other bright spot in the employment picture is the retail trade sector, which makes up just 16 percent of total regional employment but has added about 0.25 percentage point to annual job growth in the past four years. This sector, which consists of employment in retail outlets such as food stores, restaurants, department stores, clothing stores, and building supply stores, has benefited largely from gains in consumer income. Unfortunately, many of the new jobs in retailing are relatively low paying; on average, workers earn only about 70 percent of the median earnings of workers in the region. ${ }^{2}$

The relatively strong gains in employment in the region's service and retail trade sectors are not entirely surprising. Because industries in these sectors were so hard hit by the region's downturn, a rebound toward prerecession employment levels was likely. Employment trends nationwide have also favored growth in these sectors. Moreover, the importance of the service sector to the local economy has increased in the region over the past several decades as manufacturing employment has declined. ${ }^{3}$ Still, the recovery in these sectors is striking: job levels in several segments of services and retail trade have surpassed prerecession peaks and have resumed their long-term growth trends.

\section{The Employment Picture in Other Sectors}

Despite rapid job creation in services and retail trade, total employment gains in the New York-New Jersey region in 1993-96 reached only about 380,000 jobs (Table 1). Growth was restrained largely because of the

Chart 1

Industry Contribution to Job Growth: The New York-New Jersey Region and the Nation
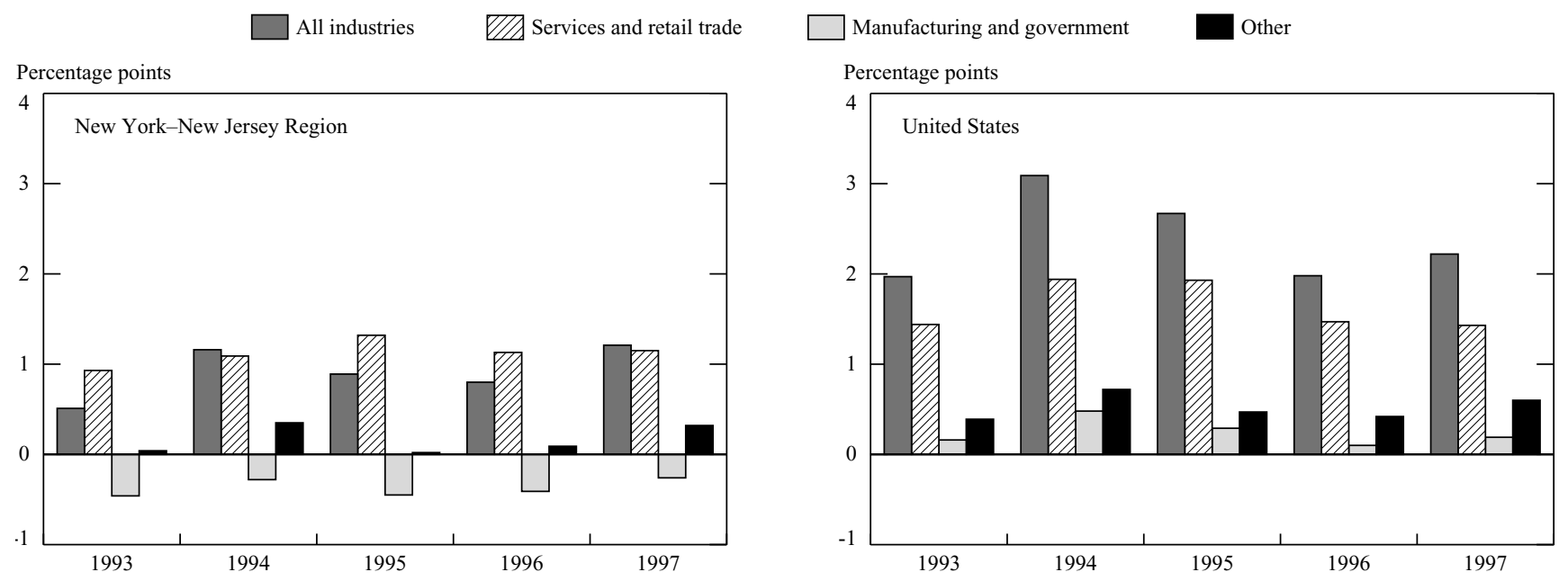

Source: U.S. Department of Labor.

Notes: "Other" comprises wholesale trade; construction; finance, insurance, and real estate; and transportation, communications, and public utilities. Figures for 1997 are for the January-June period and reflect year-over-year contributions to job growth. 
Table 1

New York-New Jersey Job Gains and Losses by Major Sector: 1993-96

\begin{tabular}{lrrr} 
Industry & Total & New York State & New Jersey \\
\hline Services & 414,000 & 270,400 & 143,600 \\
Retail trade & 91,300 & 56,000 & 35,300 \\
$\quad$ Subtotal & 505,300 & 326,400 & 178,900 \\
Manufacturing & $-136,200$ & $-91,500$ & $-44,700$ \\
Government & $-44,100$ & $-44,600$ & 500 \\
$\quad$ Subtotal & $-180,300$ & $-136,100$ & $-44,200$ \\
Other & 54,500 & 2,100 & 52,400 \\
All industries & 379,500 & 192,400 & 187,100
\end{tabular}

Source: U.S. Department of Labor.

a" Other" comprises wholesale trade; construction; finance, insurance, and real estate; and transportation, communications, and public utilities.

elimination of 180,000 jobs in the manufacturing and government sectors-sectors that together account for about one-third of total regional employment. Although the region has been losing manufacturing jobs for several decades, the cuts during this recovery have been unusually severe. To avoid the region's relatively high production costs, many companies have moved their production facilities to other parts of the United States, notably the South and Southwest. ${ }^{4}$ As a result, regional manufacturing employment has suffered, with job losses divided proportionately between New York and New Jersey.

In the government sector, significant downsizings at the state and local levels and minor federal tightening have slashed about 44,000 jobs, virtually all of them in New York State. The heavy New York losses reflect an ongoing pattern of cutbacks in New York City's local government, with 50,000 city government jobs eliminated over the 1993-96 period. Although state and city job losses eased from 26,700 in 1995 to just 14,300 in 1996, they continued to drag down overall growth rates. Fortunately, the government sector in New Jersey fared much better, expanding payrolls by about 500 jobs in this period.

The remaining sectors of the economyconstruction, wholesale trade, finance, transportation, communications, and public utilities - make up about 22 percent of total regional employment. Together, they generated roughly 54,500 new jobs in the 1993-96 period. During the recovery, several industries in these sectors, including banking, insurance, and communications, were hurt by restructurings and downsizings. From the trough of the recession through 1996, the region shed more than 34,000 banking jobs, and employment gains in cable television and other electronic media just barely managed to offset losses in other communications industries.

Losses in New Jersey's finance, transportation, communications, and public utilities sectors were less than those of New York, as modest gains in transportation and some finance sectors helped compensate for faltering growth and declines in other sectors. From 1993 to 1996, increased activity at Newark airport helped to boost transportation employment by 21,300 jobs, and the relocation of back office jobs from New York to New Jersey added more than 8,600 jobs to New Jersey's securities sector. On the whole, however, despite a brief spurt in 1993-94, these industries have contributed very little to the region's employment recovery.

\section{Geographic Breakdown of Job Growth}

During the first three years of the region's recovery, job growth advanced relatively evenly across New York State and New Jersey. As the recovery has progressed, however, employment has picked up steam in the New York City metropolitan area (New York City, Long Island, and Putnam, Rockland, and Westchester counties). Job creation there accelerated from 0.3 percent in 1995 to 1.1 percent in 1996. Meanwhile, employment growth in the upstate and western regions of New York has been disappointing, slipping to 0.1 percent in 1996 and averaging just

\section{Regional manufacturing employment has suffered, with job losses divided proportionately between New York and New Jersey.}

0.7 percent in the first half of 1997. By contrast, throughout New Jersey, employment growth has maintained a relatively steady pace of about 1.3 percent. As a result, although New Jersey is only half the size of New York, New Jersey has generated approximately the same number of jobs as New York during the region's recovery.

The engines of employment in the New York metropolitan area parallel those of the region, with services and retail trade leading job growth (Chart 2). The metropolitan area added jobs in business and consumer services at a rate close to the nation's, reaching 4.8 percent in 1996 and 4.5 percent in the first half of 1997. Retail jobs there rose 1.5 percent in 1996 and 1.7 percent in the first half of 1997. 
Chart 2

\section{Annual Employment Growth:} New York and the United States
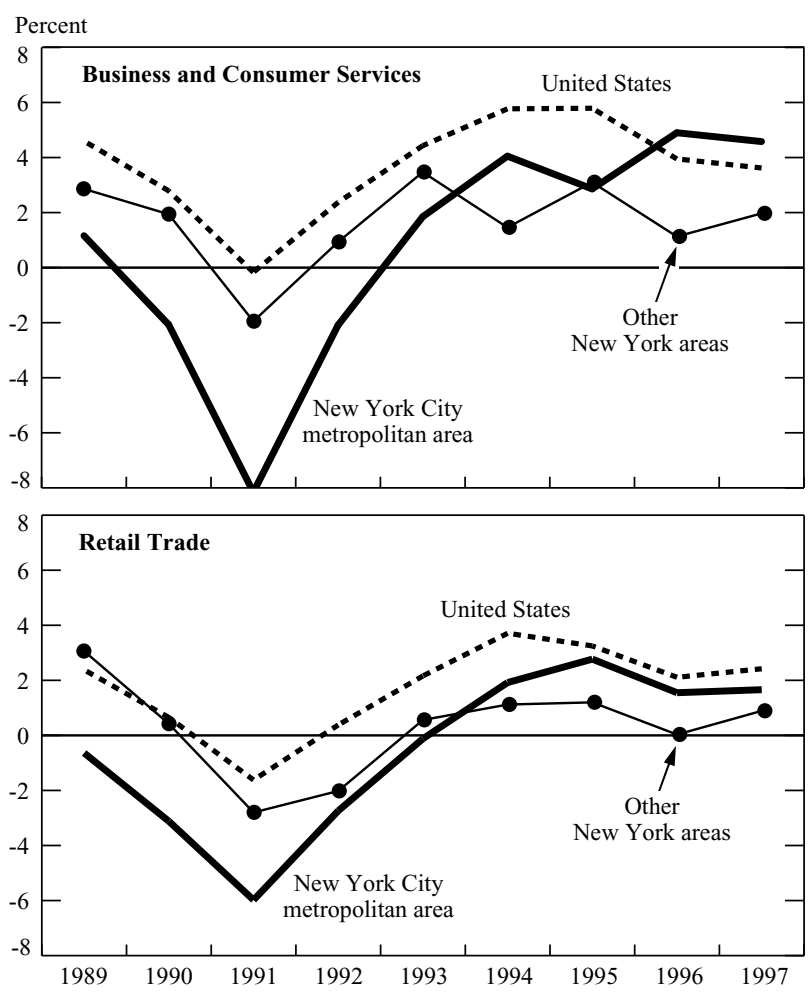

Source: U.S. Department of Labor.

Notes: The New York City metropolitan area comprises New York City, Long Island, and Putnam, Rockland, and Westchester counties. Figures for 1997 are for the January-June period and reflect year-over-year job growth.

Outside of the New York metropolitan area, however, both services and retail trade have suffered lagging demand. Gains in business and consumer services have been weak compared with those in the metropolitan area: tepid growth of 1.1 percent in 1996 rose to an annualized rate of around 2 percent in the first half of 1997. Employment in retail outlets in upstate and western New York was flat in 1996 and grew just 0.9 percent in the first half of 1997. These growth rates could not offset losses in manufacturing and government employment in upstate and western New York, and the rate of job growth decelerated sharply.

What factors account for the uneven distribution of job growth in New York State? First, differences in employment demand reflect the greater breadth of the market for services and retail trade in the metropolitan area. The resurgence of tourism has contributed to a boom in New York City's retail sector. Business services in the metropolitan area have not only enjoyed strong consumer demand from tourists and local residents, but have also benefited from rising national and international demand. Hotel occupancy rates are at record levels, passenger arrivals at the area's three major airports are increasing, and convention business has rebounded from recession lows.

Second, trends in wage and salary income have contributed to the divergence between the metropolitan area and the upstate and western regions of New York. From 1992 to 1995, wages and salaries advanced 4 percent a year on average in the New York metropolitan area; in 1996, they nearly doubled that rate, fueled by high profits on Wall Street. Wages in finance, insurance, and real estate (FIRE) rose an exceptionally large 15 percent in 1996, but even non-FIRE wages rose more than 5 percent. In contrast, wage gains in upstate and western New York have been slim, averaging just 3 percent during the $1992-96$ period. Because these gains in nominal income just met inflation, which averaged 2.9 percent in 1996, purchasing power does not appear to have increased substantially outside of the New York metropolitan area.

Although the unusually large job gains in the metropolitan area go a long way toward explaining the state's uneven performance, weak growth in upstate and western New York remains a cause for concern. There, the manufacturing sector accounts for about 16 percent of total employment (compared with 8.5 percent in the metropolitan area). Because demand for durable goods typically declines when the economy slows, these areas are particularly vulnerable to national economic downturns. Thus, in the event that the nation's growth

Table 2

Employment in the New York-New Jersey Region: Past and Projected Growth

Annual Percentage Change

\begin{tabular}{lrrrr} 
& 1994 & 1995 & 1996 & 1997 \\
\hline New York and New Jersey & 1.2 & 0.9 & 0.8 & 1.1 \\
New York State & 0.9 & 0.7 & 0.6 & 0.9 \\
Private sector & 1.1 & 1.3 & 1.0 & 1.3 \\
Public sector & -0.1 & -1.9 & -1.0 & -0.6 \\
New York City & 0.9 & 0.3 & 1.1 & 1.3 \\
$\quad$ Private sector & 1.5 & 1.3 & 1.6 & 1.8 \\
Public sector & -2.2 & -4.4 & -1.4 & -1.2 \\
New Jersey & 1.8 & 1.3 & 1.2 & 1.6 \\
Private sector & 2.1 & 1.5 & 1.4 & 1.7 \\
Public sector & 0.5 & 0.1 & -0.4 & -0.2
\end{tabular}

Sources: U.S. Department of Labor; authors' projections.

Note: Figures for 1997 are projections. 
rate moderates, employment advances in the New York metropolitan area may not continue to offset poor growth in other areas of the state.

\section{EMPLOYMENT UPDATE}

Despite some weaknesses, the employment picture for the New York-New Jersey region as a whole is relatively good. Employment growth is expected to accelerate modestly to 1.1 percent in 1997, from 0.8 percent in 1996, yielding 129,000 new jobs (Table 2). This forecast is slightly above our January forecast of 0.9 percent growth in $1997,{ }^{6}$ reflecting the revised estimates of new jobs created in the region in 1996 and the significant improvement in the forecast of national economic activity this year. ${ }^{7}$

The New York metropolitan area will continue to thrive. In New York City alone, job growth of 1.3 percent should produce about 44,000 jobs. If this trend continues, the city could begin to see a decline in its unemployment rate, which reached 10 percent in June 1997. The employment outlook in New Jersey is also bright, with growth of 1.6 percent expected to create about 58,000 new jobs in 1997. By the end of the year, New Jersey will have recovered all the jobs it lost during the recession of the early 1990s and will have advanced to a new employment high.

The slow expansion in upstate and western New York will continue to generate relatively few jobs, about 14,000 in total in 1997. As a result, the rate of growth for the state as a whole will fall short of that for the New York City area, reaching only 0.9 percent, a gain of about 71,000 jobs. Given the fact that upstate and western New York account for 3 million jobsa large concentration nearly equal to New Jersey'sthat number is somewhat disappointing. So far, however, the New York metropolitan area's strong performance has helped to keep the region's job recovery on track. Barring a major slowdown in the national economy, the region's modest growth should continue in the near term.

\footnotetext{
Notes

1. Upstate and western New York account for 3 million jobs, a total greater than that for many small states and about equal to that for New Jersey. The New York metropolitan area claims 58 percent of total state employment, or some 4.6 million jobs.

2. This estimate is based on tabulations of annual earnings of fulltime, full-year workers from the U.S. Bureau of the Census (1996).

3. See Orr (1997).

4. For a discussion of developments in New York State's manufacturing sector, see Howe and Leary (1996).

5. Although Buffalo, Rochester, and Syracuse realized some increase in demand from Canadian shoppers, overall growth was meager compared with that in the New York metropolitan area.

6. See Orr and Rosen (1997).

7. The current consensus forecast for real GDP growth in 1997 is 3.6 percent, compared with 2.3 percent in January (Blue Chip Economic Indicators 1997).
}

\section{REFERENCES}

Blue Chip Economic Indicators. 1997. Vol. 22, no. 9 (September 10).

Howe, Howard, and Mark Leary. 1996. "New York State's Merchandise Export Gap." Federal Reserve Bank of New York Current Issues in Economics and Finance 2, no. 12.

Orr, James. 1997. "Industrial Restructuring in the New York Metropolitan Area." Federal Reserve Bank of New York Economic Policy Review 3, no. 1.

Orr, James, and Rae D. Rosen. 1997. "1997 Job Outlook: The New York-New Jersey Region.” Federal Reserve Bank of New York Current Issues in Economics and Finance 3, no. 1.

U.S. Bureau of the Census. 1996. 1996 March Current Population Survey.

The views expressed in this article are those of the authors and do not necessarily reflect the position of the Federal Reserve Bank of New York or the Federal Reserve System.

Second District Highlights, a supplement to Current Issues in Economics and Finance, is published by the Research and Market Analysis Group of the Federal Reserve Bank of New York. Dorothy Meadow Sobol is the editor.

For more information on the Second District, visit our regional economy web site (www.ny.frb.org/rmaghome/regional). To subscribe to Current Issues, write to the Public Information Department, Federal Reserve Bank of New York, 33 Liberty Street, New York, N.Y. 10045-0001, or call 212-720-6134. 


\section{Economic Trends in the Second District}

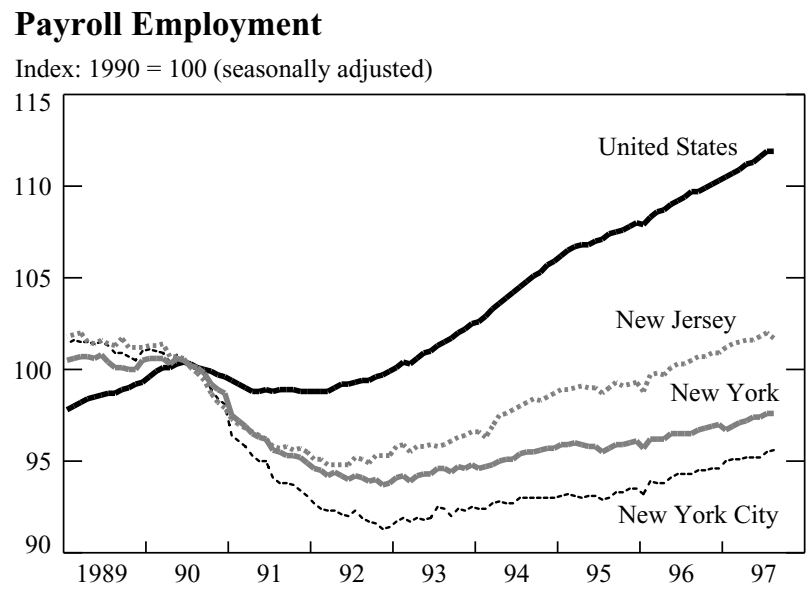

Payroll Employment in Selected Sectors

New York and New Jersey Combined

Index: $1990=100$ (seasonally adjusted)

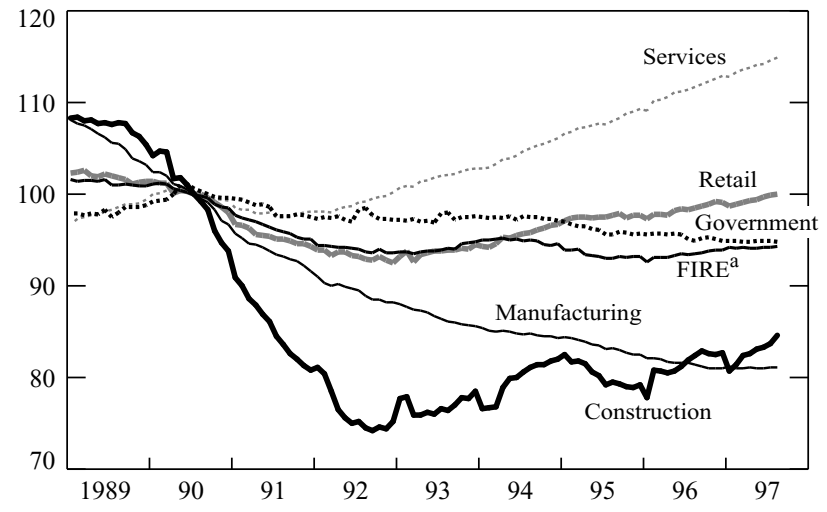

Regional and National Inflation

Twelve-Month Percentage Change in Consumer Price Index

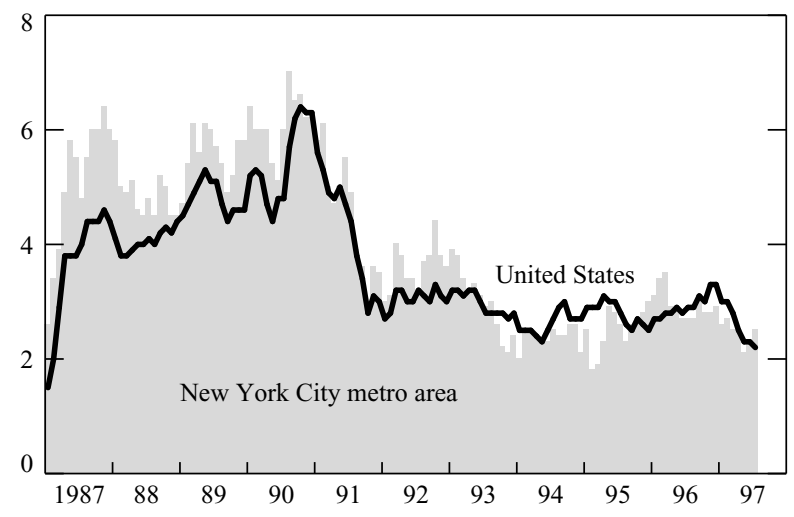

Sources: New York, New Jersey, and Connecticut Departments of Labor; U.S. Department of Labor, Bureau of Labor Statistics; U.S. Department of Commerce, Bureau of the Census.

${ }^{\mathrm{a}} \mathrm{FIRE}=$ finance, insurance, and real estate.

${ }^{\mathrm{b}}$ Upstate N.Y. comprises the four metropolitan areas listed as well as Binghamton, Elmira, Glens Falls, Jamestown, and Utica-Rome.

\section{Unemployment Rates}

Percent (seasonally adjusted)

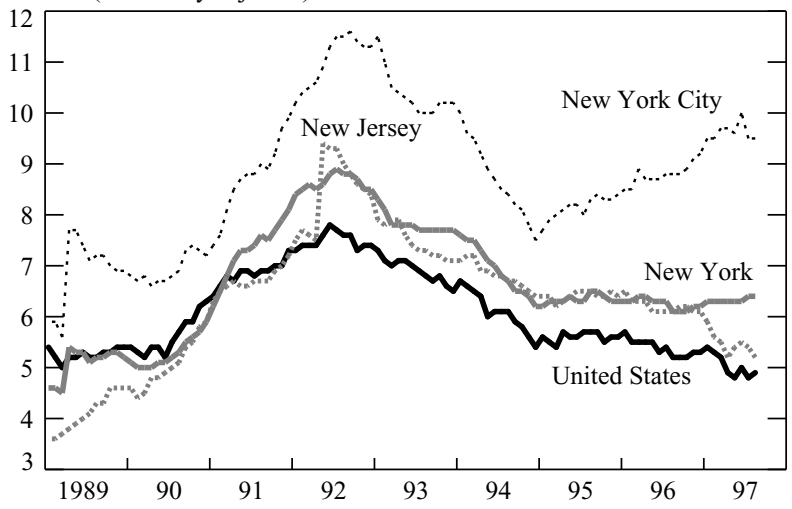

Job Growth in the Nation and Selected Metropolitan Areas June-August 1996 to June-August 1997

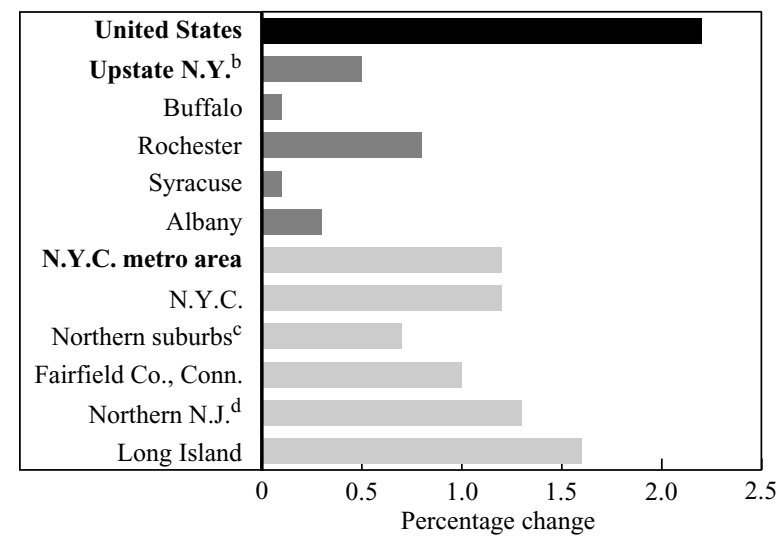

Housing Permits in New York and New Jersey Combined Twelve-Month Moving Average, Annual Rate Thousands

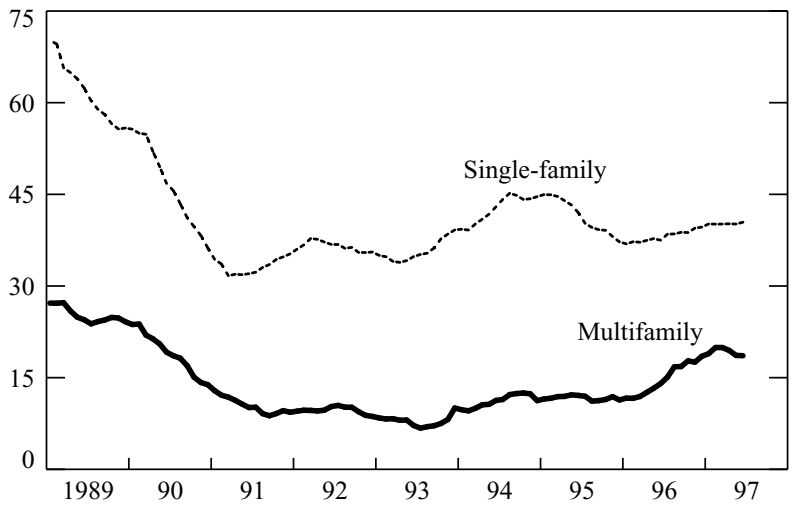

${ }^{\mathrm{c}}$ The northern suburbs of N.Y.C. comprise Dutchess, Orange, Putnam, Rockland, and Westchester Counties, N.Y., and Pike County, Pa.

${ }^{\mathrm{d}}$ Northern N.J. comprises Bergen, Essex, Hudson, Hunterdon, Mercer, Middlesex, Monmouth, Morris, Ocean, Passaic, Somerset, Sussex, Union, and Warren Counties. 